\title{
LOCAL COMMUNITIES PERCEPTION ON THE IMPACT OF PRAMBANAN JAZZ FESTIVAL
}

\author{
Indriyani Handyastuti ${ }^{(1)}$, Dwiesty Dyah Utami ${ }^{(2)^{*}}$, Vanda Nirma Audita ${ }^{(3)}$ \\ (1)(3) Program Studi Manajemen Konvensi dan Event, Sekolah Tinggi Pariwisata Bandung \\ (2) Program Studi Manajemen Bisnis Perjalanan, Sekolah Tinggi Pariwisata Bandung \\ inh@stp-bandung.ac.id, dwiesty.dyah@gmail.com, van@stp-bandung.ac.id
}

Submitted: 14 September 2019 Revised:17 March 2020

Accepted: 29 September 2020

\begin{abstract}
The development of the organization of the event now starts to vary and provides a valuable and impressive experience for many people. So, from that along with its development, the event appeared increasingly unique both in terms of concept to the venue used. One of the events that have its uniqueness is the festival. In this case, Prambanan Jazz Festival is one of the types of events that are used as the focus of research. Organizing an event can have an impact on the surrounding community, both in terms of social, environmental, and economical. Communities in the surrounding environment will have different perceptions about the impact of the event. An event can be considered as successful if the community perceives the positive benefit from the event and give considerable support. The research method used in this study is quantitative with descriptive analysis. The purpose of this study was to find out how local people perceive the impact of the implementation of Prambanan Jazz. Festival on social, environmental, and economic impacts. The result of this study indicates that Prambanan Jazz Festival had a little social impact on local communities. The Prambanan Jazz Festival does not provide significant environmental impact from some of the main aspects of this study. In addition, the implementation of the Prambanan Jazz. Festival has not affected the economy around the event area due to the absence of programs made by the event organizers to support the economy of the surrounding community.
\end{abstract}

Keywords: Local Communities Perception, Prambanan Jazz Festival, The Impact of Event

\section{INTRODUCTION}

The development of the Event Industry has given a variety of colours to the types of service industry activities that are synonymous with providing services. The Event Industry is complex and involves many people with the same goals, so it can have an impact on the parties involved.

The parties involved in an event are stakeholders who have certain interests and roles in an event both individuals, associations, and internal or external organizations (Getz \& Page, 2014; Wilson et al., 2017). The internal party in an event is the organizer, while the external party is the government, the community, and other related parties (Getz \& Page, 2014).

Organizing an event can have a positive or negative impact on stakeholders. According to Raj \& Musgrave (2009), an event can have an impact based on the Triple Bottom Line (TBL), namely; impacts on the economy, impacts on socio-culture, and impacts on the environment. 
These impacts can be positive or negative, as well as tangible and intangible. According to Getz \& Page (2014), the event is divided into several types, and one of them is the festival. A Festival is an event that has a certain theme and is held regularly or at certain times (Raj \& Musgrave, 2009).

One of the festivals in Indonesia that is known to foreign countries is Prambanan Jazz Festival. Prambanan Jazz Festival is one of the jazz music festivals in Indonesia held in the courtyard of Prambanan Temple, Yogyakarta. Prambanan Jazz Festival carries the exoticism of the magnificence of Prambanan Temple's artwork, which is one of the world-recognized Indonesian cultural masterpieces (Alimi, 2017).

Prambanan Jazz Festival 2017 has been held for the third time and is based on the results of the interviews visited by approximately 33,000 visitors from within and outside the country. This makes Prambanan Jazz Festival a big event that can provide positive and negative impacts on local communities. As expressed by Gong (2012), "Mega-events have a wide range of impact, both positive and negative, on host community or stakeholders".

The local people who might feel the positive and negative effects of the implementation of the Prambanan Jazz Festival event are people who live in villages that are located near or directly adjacent to the event venue, Prambanan Temple. Which in this case are Bokoharjo Village, Madurejo Village, Tamanmartani Village, Tlogo Village, and Kebon Dalem Kidul Village. Therefore, stakeholder support becomes important in the success of organizing an event (Todd, Leask, \& Ensor, 2017) where such support can be obtained if they believe that the implementation of an event will benefit them (Osaka \& Bellamy, 2020). The same thing was stated by Parent (2016) and
Liu (2016) that when the community as one of the stakeholders felt there was an advantage for them in organizing an event, the community would tend to support the implementation of the event. This indicates that the importance of public perception about the impact of organizing an event.

Based on this background, research on the "Local Communities Perception on the Impact of Prambanan Jazz Festival" is important. The purpose of this study was to determine the extent of the economic, sociocultural, and environmental impacts of the implementation of the Prambanan Jazz Festival event.

\section{LITERATURE REVIEW}

According to Raj \& Musgrave (2009), the festival can be concluded as a group meeting or an event that focuses on a theme that is held repeatedly or in a certain period. This type of festival consists of film festivals, music festivals, art festivals, and cultural festivals.

Prambanan Jazz Festival in this study belongs to the category of music festivals, because this event is a musical performance featuring musical performances from national and international jazz musicians.

According to Dwyer, Forsyth, \& Spurr (2015), organizing an event can have social, economic, and environmental impacts based on certain long-term activities in the targeted area. This is consistent with Slabbert, Africa, \& Oberholzer (2011) statement that events or festivals provide social, economic, and environmental impacts where there is activity at the event.

Raj \& Musgrave (2009) adds that the event can have positive and negative in social, economic, and environmental impacts on the host community. The impact of organizing an event can be seen in table 1 of the Three Pillar Impacts of Event. 
Table 1. The Three Pilar Impacts Of Event

\begin{tabular}{|c|c|c|}
\hline \multicolumn{3}{|c|}{ E $V$ E $\mathbf{T}$} \\
\hline $\begin{aligned} & \text { SOCIAL } \\
& \text { Positive } \\
& \text { - } \text { Induced development and } \\
& \text { construction expenditure } \\
& \text { - } \text { Long-term promotional } \\
& \text { benefits } \\
& \text { - } \text { Civic Pride } \\
& \text { - } \text { Community development } \\
& \text { - } \text { Increased employment } \\
& \text { Negative } \text { opportunities } \\
& \text { - } \text { Future use of infrastructure } \\
& \text { not maximized } \\
& \text { - } \text { Interruption of normal } \\
& \text { - } \text { business } \\
& \text { - } \text { Mesident Exodia Impacts } \\
& \text { - } \text { Community apathy and } \\
& \text { - } \text { antagonism } \\
& \text { - } \text { Increased risk of a security } \\
& \text { Unequal distribution of } \\
& \text { wealth }\end{aligned}$ & $\begin{aligned} & \text { ENVIRONMENTAL } \\
& \text { Positive } \\
& \text { - } \text { Raising awareness of } \\
& \text { environmental issues } \\
& \text { - } \text { Development of } \\
& \text { wasteland } \\
& \text { - } \text { Long-term } \\
& \text { conservation area } \\
& \text { Negative } \\
& \text { - } \text { Site/location damage - } \\
& \text { - } \text { short-and long-term } \\
& \text { - } \text { Noiste and pollution } \\
& \text { - } \text { Traffic disruption and } \\
& \text { congestion } \\
& \text { - } \text { Increase in energy } \\
& \text { demands and other } \\
& \text { natural resources }\end{aligned}$ & $\begin{array}{ll}\text { ECONOMY } \\
\text { Positive } \\
\text { - } & \begin{array}{l}\text { Direct/indirect } \\
\text { expenditure }\end{array} \\
\text { - } & \text { Increased property value } \\
\text { due to regeneration } \\
\text { - } & \text { Additional trade and } \\
\text { business development } \\
\text { - } \\
\text { Induced development } \\
\text { and construction } \\
\text { expenditure } \\
\text { Event product extension } \\
\text { Negative } \\
\text { - Cost of event failure to } \\
\text { the local/national } \\
\text { economy } \\
\text { The inflated price of } \\
\text { products, services, and } \\
\text { amenities } \\
\text { Unequal distribution of } \\
\text { wealth }\end{array}$ \\
\hline
\end{tabular}

Source: Raj \& Musgrave (2009)

\section{RESEARCH METHOD}

This research uses quantitative methods to prove or confirm the effects of the implementation of the Prambanan Jazz Festival. Data collection methods used in this study were questionnaires, interviews, and observations. The questionnaire in this study was given to the head of the family of 5 (five) villages namely; Bokoharjo Village, Madurejo Village, Tamanmartani Village, Tlogo Village, and Kebon Dalem Kidul Village were aware of the holding of the Prambanan Jazz Festival event. Through questionnaire data, we would like to know the extent of the perceived impact and how the community is involved in the implementation of the Prambanan Jazz Festival.

As for the interview data collection method, researchers used interview guidelines by asking structured questions to four groups of respondents. The first group of respondents to the interview was the government, which in this case, the relevant government agencies, namely the marketing staff of the Sleman District Tourism Office. Information from the group of respondents was explored about the role of the government in making special regulations on the implementation of the Prambanan Jazz Festival. The second group of respondents is the Manager of Prambanan Temple, who in this case is the head of the marketing and development section of Prambanan Temple. Information from the group of respondents was explored regarding the involvement of Prambanan Temple managers and the organizers of the Prambanan Jazz Festival on the comfort and safety of the Prambanan Temple during the event. The third group of respondents is the organizer of the Prambanan Jazz Festival Event, which in this case is the project manager of PT. Rajawali Indonesia Communication. From this side, it was explored whether in determining the Prambanan Jazz Festival theme the organizers of the activity included elements of local 
culture. The fourth group of respondents is Community Leaders, which in this case are 5 (five) Village Heads in Prambanan District namely; Bokoharjo Village Head, Madurejo Village Head, Desa Tamanmartani Village, Tlogo Village Head, and Kebon Dalem Kidul Village Head. From these parties, the researchers wanted to find out whether there was a cultural value of the community in the implementation of the Prambanan Jazz Festival.

As for the observation data collection method, researchers used a data collection tool in the form of a checklist. The population in this study are people who live in villages that are located near or directly adjacent to the event venue, namely villages in Prambanan Subdistrict, amounting to 17,060 families.

Table 2. Family Head Data

\begin{tabular}{ll}
\hline Village & Family Head \\
\hline Desa Bokoharjo & 4.179 \\
\hline Desa Madurejo & 4.624 \\
\hline Desa Tamanmartani & 5.569 \\
\hline Desa Tlogo & 1.432 \\
\hline Desa Kebon Dalem Kidul & 1.256 \\
\hline TOTAL & 17.060 \\
\hline
\end{tabular}

Source: Data Processed by the researcher

In this study, researchers used probability sampling techniques as the main data collection techniques in the form of questionnaires and non-probability sampling as a technique of retrieving supporting data in the form of interviews. As for the sampling technique in probability sampling, researchers chose to use Cluster Random Sampling is a regional sampling technique used to determine the sample if the object to be studied or the data source is very broad, for example, residents from a country, province, or district (Sugiyono, 2015).

The sample in this study was based on the Slovin formula with a significance level of 0.1 amounting to 100 people (Sugiyono, 2017). To determine the sample size in each village carried out with proportional allocation so that the sample taken is more proportional, the distribution is as follows:
Table 3. The Number of Sample Calculation

\begin{tabular}{llll}
\hline No & Village & Calculation & $\begin{array}{l}\text { Number } \\
\text { of People }\end{array}$ \\
\hline 1 & $\begin{array}{l}\text { Desa } \\
\text { Bokoharjo }\end{array}$ & $\frac{4179}{17060} \times 100=24,49$ & 25 \\
\hline 2 & $\begin{array}{l}\text { Desa } \\
\text { Madurejo }\end{array}$ & $\frac{4624}{17060} \times 100=27,10$ & 27 \\
\hline 3 & $\begin{array}{l}\text { Desa } \\
\text { Taman } \\
\text { Martani }\end{array}$ & $\frac{5569}{17060} \times 100=32,64$ & 33 \\
\hline 4 & $\begin{array}{l}\text { Desa Tlogo } \\
\text { Nesa }\end{array}$ & $\frac{1432}{17060} \times 100=8,39$ & 8 \\
\hline & $\begin{array}{l}\text { Kebon } \\
\text { Dalem } \\
\text { Kidul }\end{array}$ & $\frac{1256}{17060} \times 100=7,36$ & 7 \\
\hline & Total
\end{tabular}

Source: Data Processed by the researcher

The data analysis technique used in this study is a descriptive analysis. According to Creswell (2014), descriptive analysis is used for the variables of a study including the description of research results in the form of averages, standard deviations, and the distance between the lowest number and the highest number. In this study, the researchers tried to describe the phenomenon of research by describing the findings in the form of numbers and interpreting the data with interview data.

\section{RESULT AND DISCUSSION}

Table 4. Data of Social, Environmental, and Economic Impact Findings

\begin{tabular}{|c|c|c|c|c|}
\hline \multirow{2}{*}{ NO } & \multirow{2}{*}{ INDICATOR } & YES & NO & TOTAL \\
\hline & & $\%$ & $\%$ & $\%$ \\
\hline 1 & $\begin{array}{l}\text { Facilities and/or } \\
\text { infrastructure built by the } \\
\text { government specifically } \\
\text { for the Prambanan Jazz } \\
\text { Festival event needs }\end{array}$ & 1 & 99 & 100 \\
\hline 2 & $\begin{array}{l}\text { Programs related to } \\
\text { community development } \\
\text { were held specifically to } \\
\text { support the PJF event }\end{array}$ & 0 & 100 & 100 \\
\hline 3 & $\begin{array}{l}\text { Improving the quality of } \\
\text { public facilities due to the } \\
\text { PJF event }\end{array}$ & 2 & 98 & 100 \\
\hline 4 & $\begin{array}{l}\text { Many international } \\
\text { activities related to } \\
\text { culture took place in my } \\
\text { region after the PJF event } \\
\text { was held }\end{array}$ & 20 & 80 & 100 \\
\hline 5 & $\begin{array}{l}\text { Special ticket } \\
\text { classification for } \\
\text { communities around } \\
\text { Prambanan Temple }\end{array}$ & 0 & 100 & 100 \\
\hline
\end{tabular}


Indriyani Handyastuti, Dwiesty Dyah Utami, dan Vanda Nirma Audita:

Local Communities Perception on the impact of Prambanan Jazz Festival

\begin{tabular}{|c|c|c|c|c|}
\hline \multirow{2}{*}{ NO } & \multirow{2}{*}{ INDICATOR } & YES & No & TOTAL \\
\hline & & $\%$ & $\%$ & $\%$ \\
\hline 6 & $\begin{array}{l}\text { PJF is one of the } \\
\text { entertainment facilities } \\
\text { for the surrounding } \\
\text { community }\end{array}$ & 11 & 89 & 100 \\
\hline 7 & $\begin{array}{l}\text { The PJF event preserves } \\
\text { local culture }\end{array}$ & 12 & 88 & 100 \\
\hline 8 & $\begin{array}{l}\text { PJF Event makes paid } \\
\text { activities free }\end{array}$ & 3 & 97 & 100 \\
\hline 9 & $\begin{array}{l}\text { There was some damage } \\
\text { in my area after the PJF } \\
\text { event }\end{array}$ & 8 & 92 & 100 \\
\hline 10 & $\begin{array}{l}\text { The local community } \\
\text { house can be rented out } \\
\text { because of the PJF }\end{array}$ & 3 & 97 & 100 \\
\hline 11 & $\begin{array}{l}\text { Ethnic tensions have } \\
\text { occurred since the PJF } \\
\text { event }\end{array}$ & 2 & 98 & 100 \\
\hline 12 & $\begin{array}{l}\text { The PJF event raises the } \\
\text { appearance of } \\
\text { prostitution }\end{array}$ & 0 & 100 & 100 \\
\hline 13 & $\begin{array}{l}\text { The PJF event causes } \\
\text { respondents to } \\
\text { temporarily evacuate to } \\
\text { other places }\end{array}$ & 1 & 99 & 100 \\
\hline 14 & $\begin{array}{l}\text { Residents objected and } \\
\text { did not agree to the } \\
\text { holding of the PJF event }\end{array}$ & 0 & 100 & 100 \\
\hline 15 & $\begin{array}{l}\text { The crime occurred } \\
\text { during the } \\
\text { implementation of the } \\
\text { PJF }\end{array}$ & 0 & 100 & 100 \\
\hline 16 & $\begin{array}{l}\text { Is the existence of PJF } \\
\text { causing garbage } \\
\text { problems? }\end{array}$ & 0 & 100 & 100 \\
\hline 17 & $\begin{array}{l}\text { I can rent my house for a } \\
\text { homestay during the } \\
\text { Prambanan Jazz Festival } \\
\text { event }\end{array}$ & 15 & 85 & 100 \\
\hline 18 & $\begin{array}{l}\text { The committee invites the } \\
\text { public to cooperate in } \\
\text { providing } \\
\text { accommodation for } \\
\text { visitors to the Prambanan } \\
\text { Jazz Festival event }\end{array}$ & 3 & 97 & 100 \\
\hline 19 & $\begin{array}{l}\text { I feel disturbed by the } \\
\text { congestion caused by the } \\
\text { jazz festival Prambanan } \\
\text { event }\end{array}$ & 0 & 100 & 100 \\
\hline 20 & $\begin{array}{l}\text { Are there any efforts to } \\
\text { increase the beauty of the } \\
\text { general area around } \\
\text { Prambanan Temple in } \\
\text { connection with the } \\
\text { holding of the Prambanan } \\
\text { Jazz Festival event? }\end{array}$ & 5 & 95 & 100 \\
\hline 21 & $\begin{array}{l}\text { Are there road } \\
\text { improvements for the } \\
\text { implementation of the } \\
\text { Prambanan Jazz Festival } \\
\text { event? }\end{array}$ & 0 & 100 & 100 \\
\hline 22 & $\begin{array}{l}\text { Can the local community } \\
\text { improve the roads } \\
\text { mentioned above? }\end{array}$ & 0 & 100 & 100 \\
\hline 23 & $\begin{array}{l}\text { Prambanan Jazz Festival } \\
\text { activities provide } \\
\text { additional tourist } \\
\text { facilities in the } \\
\text { surrounding area }\end{array}$ & 3 & 97 & 100 \\
\hline
\end{tabular}

\begin{tabular}{|c|c|c|c|c|}
\hline \multirow{2}{*}{ NO } & \multirow{2}{*}{ INDICATOR } & \multirow{2}{*}{$\begin{array}{l}\text { YES } \\
\%\end{array}$} & \multirow{2}{*}{$\begin{array}{l}\text { NO } \\
\%\end{array}$} & \multirow{2}{*}{$\begin{array}{l}\text { TOTAL } \\
\%\end{array}$} \\
\hline & & & & \\
\hline 24 & $\begin{array}{l}\text { Is the Prambanan Jazz } \\
\text { Festival event an effort to } \\
\text { conserve the environment } \\
\text { in the area around } \\
\text { Prambanan Temple? }\end{array}$ & 4 & 96 & 100 \\
\hline 25 & $\begin{array}{l}\text { After the Prambanan Jazz } \\
\text { Festival event took place, } \\
\text { there was damage to } \\
\text { facilities belonging to } \\
\text { local communities? }\end{array}$ & 0 & 100 & 100 \\
\hline 26 & $\begin{array}{l}\text { Do residents feel air } \\
\text { pollution such as dust, } \\
\text { smoke, and others during } \\
\text { the implementation of the } \\
\text { Prambanan Jazz Festival } \\
\text { event? }\end{array}$ & 8 & 92 & 100 \\
\hline 27 & $\begin{array}{l}\text { Did electricity and water } \\
\text { disruptions occur during } \\
\text { the Prambanan Jazz } \\
\text { Festival event? }\end{array}$ & 0 & 100 & 100 \\
\hline 28 & $\begin{array}{l}\text { Did environmental } \\
\text { damage occur around the } \\
\text { Prambanan Temple area } \\
\text { caused by the holding of } \\
\text { the Prambanan Jazz } \\
\text { Festival event? }\end{array}$ & 0 & 100 & 100 \\
\hline 29 & $\begin{array}{l}\text { There are direct and } \\
\text { indirect economic } \\
\text { impacts after the } \\
\text { implementation of the } \\
\text { Prambanan Jazz Festival }\end{array}$ & 21 & 79 & 100 \\
\hline 30 & An increase in tourists & 53 & 47 & 100 \\
\hline 31 & $\begin{array}{l}\text { Changes in economic } \\
\text { conditions occur }\end{array}$ & 19 & 81 & 100 \\
\hline 32 & The presence of new jobs & 18 & 82 & 100 \\
\hline
\end{tabular}

Source: Data Processed by the researcher

Table 5. Data of Social, Environmental, and Economic Impact Findings

\begin{tabular}{|c|c|c|c|c|c|c|c|}
\hline \multirow{3}{*}{ NO } & \multirow{3}{*}{ INDICATOR } & EA & $\mathbf{A}$ & $\mathbf{N}$ & D & ED & \multirow{2}{*}{$\begin{array}{l}\text { TO- } \\
\text { TAL }\end{array}$} \\
\hline & & 5 & 4 & 3 & 2 & 1 & \\
\hline & & $\%$ & $\%$ & $\%$ & $\%$ & $\%$ & $\%$ \\
\hline 1 & $\begin{array}{l}\text { I feel proud that } \\
\text { the Prambanan } \\
\text { Jazz Festival } \\
\text { event was held } \\
\text { near my } \\
\text { residence. }\end{array}$ & 8 & 68 & 13 & 8 & 3 & 100 \\
\hline 2 & $\begin{array}{l}\text { The existence of } \\
\text { the Prambanan } \\
\text { Jazz Festival } \\
\text { event made me } \\
\text { understand new } \\
\text { technologies that } \\
\text { I did not know } \\
\text { before }\end{array}$ & 1 & 2 & 46 & 39 & 12 & 100 \\
\hline 3 & $\begin{array}{l}\text { The existence of } \\
\text { the Prambanan } \\
\text { Jazz Festival } \\
\text { event made me } \\
\text { use a new } \\
\text { technology that I } \\
\text { did not know } \\
\text { before }\end{array}$ & 1 & 1 & 45 & 40 & 13 & 100 \\
\hline
\end{tabular}


Indriyani Handyastuti, Dwiesty Dyah Utami, and Vanda Nirma Audita:

Local Communities Perception on the Impact of Prambanan Jazz Festival

\begin{tabular}{|c|c|c|c|c|c|c|c|}
\hline \multirow{3}{*}{ NO } & \multirow{3}{*}{ INDICATOR } & EA & $\mathbf{A}$ & $\mathbf{N}$ & $\mathbf{D}$ & ED & \multirow{2}{*}{$\begin{array}{l}\text { TO } \\
\text { TAI }\end{array}$} \\
\hline & & 5 & 4 & 3 & 2 & 1 & \\
\hline & & $\%$ & $\%$ & $\%$ & $\%$ & $\%$ & $\%$ \\
\hline 4 & $\begin{array}{l}\text { The Prambanan } \\
\text { Jazz Festival } \\
\text { event makes the } \\
\text { Prambanan } \\
\text { Temple area } \\
\text { better known by }\end{array}$ & 14 & 40 & 17 & 21 & 8 & 100 \\
\hline 5 & $\begin{array}{l}\text { The Prambanan } \\
\text { Jazz Festival } \\
\text { event helps } \\
\text { preserve cultural } \\
\text { heritage in the } \\
\text { Prambanan area }\end{array}$ & 1 & 16 & 37 & 32 & 14 & 100 \\
\hline 6 & $\begin{array}{l}\text { The Prambanan } \\
\text { Jazz Festival } \\
\text { event made me } \\
\text { more motivated } \\
\text { to do something } \\
\text { for the } \\
\text { Prambanan } \\
\text { Temple area }\end{array}$ & 0 & 8 & 43 & 38 & 11 & 100 \\
\hline 7 & $\begin{array}{l}\text { The Prambanan } \\
\text { Jazz Festival } \\
\text { event goes } \\
\text { against local } \\
\text { culture }\end{array}$ & 1 & 11 & 36 & 40 & 12 & 100 \\
\hline 8 & $\begin{array}{l}\text { Prambanan Jazz } \\
\text { Festival Event } \\
\text { Events make a } \\
\text { difference in my } \\
\text { community }\end{array}$ & 0 & 2 & 24 & 46 & 28 & 100 \\
\hline 9 & $\begin{array}{l}\text { I became } \\
\text { embarrassed by } \\
\text { my culture after } \\
\text { watching the } \\
\text { Prambanan Jazz } \\
\text { Festival event }\end{array}$ & 0 & 3 & 26 & 34 & 37 & 100 \\
\hline 10 & $\begin{array}{l}\text { I became more } \\
\text { fond of jazz than } \\
\text { the original music } \\
\text { of my region }\end{array}$ & 0 & 3 & 23 & 48 & 26 & 100 \\
\hline 11 & $\begin{array}{l}\text { I changed my } \\
\text { dress style after I } \\
\text { watched } \\
\text { Prambanan Jazz } \\
\text { Festival }\end{array}$ & 0 & 5 & 22 & 45 & 28 & 100 \\
\hline 12 & $\begin{array}{l}\text { I changed my } \\
\text { dress style after I } \\
\text { watched } \\
\text { Prambanan Jazz } \\
\text { Festival }\end{array}$ & 0 & 5 & 22 & 45 & 28 & 100 \\
\hline 13 & $\begin{array}{l}\text { The price of a } \\
\text { rental house has } \\
\text { increased rapidly } \\
\text { after the holding } \\
\text { of the Prambanan } \\
\text { Jazz Festival } \\
\text { event }\end{array}$ & 0 & 2 & 30 & 39 & 29 & 100 \\
\hline 14 & $\begin{array}{l}\text { The selling price } \\
\text { of the house } \\
\text { increased rapidly } \\
\text { after the holding } \\
\text { of the Prambanan } \\
\text { Jazz Festival } \\
\text { event }\end{array}$ & 0 & 2 & 30 & 39 & 29 & 100 \\
\hline
\end{tabular}

\begin{tabular}{|c|c|c|c|c|c|c|c|}
\hline \multirow{3}{*}{ NO } & \multirow{3}{*}{ INDICATOR } & EA & $\mathbf{A}$ & $\mathbf{N}$ & D & ED & \multirow{2}{*}{$\begin{array}{l}\text { TO- } \\
\text { TAL }\end{array}$} \\
\hline & & 5 & 4 & 3 & 2 & 1 & \\
\hline & & $\%$ & $\%$ & $\%$ & $\%$ & $\%$ & $\%$ \\
\hline 15 & $\begin{array}{l}\text { The Prambanan } \\
\text { Jazz Festival } \\
\text { event makes the } \\
\text { mass media more } \\
\text { often cover the } \\
\text { Prambanan } \\
\text { Temple area }\end{array}$ & 14 & 40 & 17 & 21 & 8 & 100 \\
\hline 16 & $\begin{array}{l}\text { Is there a } \\
\text { Prambanan Jazz } \\
\text { Festival event } \\
\text { that local people } \\
\text { are becoming } \\
\text { more aware of the } \\
\text { importance of } \\
\text { protecting the } \\
\text { environment? }\end{array}$ & 4 & 8 & 63 & 21 & 4 & 100 \\
\hline 17 & $\begin{array}{l}\text { The manager } \\
\text { should make rules } \\
\text { for visitors to use } \\
\text { local } \\
\text { transportation } \\
\text { from a certain } \\
\text { extent to the } \\
\text { location of the } \\
\text { venue }\end{array}$ & 4 & 31 & 28 & 22 & 15 & 100 \\
\hline 18 & $\begin{array}{l}\text { I agree if this } \\
\text { activity has a } \\
\text { good impact on } \\
\text { the growth of } \\
\text { tourist facilities }\end{array}$ & 9 & 47 & 15 & 20 & 9 & 100 \\
\hline 19 & $\begin{array}{l}\text { You feel } \\
\text { disturbed by this } \\
\text { activity }\end{array}$ & 0 & 4 & 18 & 48 & 30 & 100 \\
\hline 20 & $\begin{array}{l}\text { The noise } \\
\text { pollution that was } \\
\text { released made me } \\
\text { uncomfortable }\end{array}$ & 1 & 6 & 39 & 28 & 26 & 100 \\
\hline 21 & $\begin{array}{l}\text { The event has } \\
\text { caused a direct } \\
\text { increase in the } \\
\text { value of the } \\
\text { Goods }\end{array}$ & 1 & 10 & 26 & 39 & 24 & 100 \\
\hline 22 & $\begin{array}{l}\text { The emergence of } \\
\text { new businesses } \\
\text { and the } \\
\text { development of } \\
\text { business } \\
\text { communities } \\
\text { around }\end{array}$ & 1 & 15 & 30 & 32 & 22 & 100 \\
\hline 23 & $\begin{array}{l}\text { The existence of } \\
\text { construction and } \\
\text { construction } \\
\text { induction }\end{array}$ & 2 & 3 & 34 & 37 & 24 & 100 \\
\hline
\end{tabular}

Source: Data Processed by the researcher

a. Social Impact

1) Induced Development And Construction based on the data found in table 4; it is known that the government did not make 
additional facilities or infrastructure to support the needs of the Prambanan Jazz Festival. This is because the PJF does not bring the government as an external stakeholder that is important in its implementation. This causes the PJF to not be able to be a catalyst for infrastructure development in the Prambanan Temple area, considering that the government is the decision-maker of certain regional infrastructure developments.

2) Long Term Promotional Benefits

The PJF event will still have a long-term promotional impact on Prambanan Temple. This is in accordance with the research journal Raj \& Musgrave (2009), which says that one of the positive effects of special events is to provide long-term promotions for the host/venue for the event. However, most people cannot see this for Prambanan Temple.

3) Enhanced Resident Pride

The local community did not feel proud of the PJF to take place, because the community was not included in the organization either as an event organizer or audience. So that people do not have any interest in PJF, which results in people not feeling the PJF is part of them.

4) Community Development

The government did not develop the quality of local human resources to support the implementation of the Prambanan Jazz Festival. This is because the PJF is a purely business event and does not bring the government to work together in its implementation so that the event is only held singly by the EO.

5) Increased Employment Opportunities

Prambanan Jazz Festival does not significantly reduce unemployment from surrounding communities. This is because the community is not involved in organizing the Prambanan Jazz Festival. All HR used in the operation of the PJF has been arranged by the EO.

6) Improves the Quality of Public Service There is no additional quality of public facilities carried out by the government to support the implementation of the Prambanan Jazz Festival. This is because the organizers did not cooperate with the government in holding this exhibition. In accordance with Adongo, (Sam) Kim, \& Elliot, (2019) statement, the government is part of the external stakeholders of a festival and is a policymaker in infrastructure and public service development.

7) Increase the Number of Exhibitions and Events

Prambanan Jazz Festival does not motivate the increasing number of other events held in the Prambanan Temple area.

8) Promoted Human Resources Development There is no HR training program for the community in supporting the implementation of PJF activities.

9) Technology Advancement

There is no new technology introduced to the public or used by the community through the holding of the Prambanan Jazz Festival. This is because there is no interaction between the surrounding community and the Prambanan Jazz Festival activities.

10) Improve the Image of Prambanan

Prambanan Jazz Festival does not greatly enhance the image of Prambanan Temple, because the publications that are carried out are less up to the surrounding community. This can be seen from more local people who do not know about PJF compared to those who know. In addition, this is also supported because Prambanan Jazz Festival is in demand by certain groups of people who are Jazz lovers and with middle to upper economic conditions due to the high price of tickets. So that the image of PJF in raising the popularity of Prambanan Temple is only in that segmentation, also, the surrounding community cannot enjoy PJF, causing the respondents to say that $\mathrm{PJF}$ does not raise the image of Prambanan Temple.

11) More International Cultural Activities

Prambanan Jazz Festival does not make more and more international scale cultural 
events. This is because the PJF is not a cultural festival but a music festival.

12) Heritage Preservation

Based on the data found, Prambanan Jazz Festival does not help preserve the culture in the Prambanan temple area, both physical and non-physical.

13) Increased Community Spirit

The community is not motivated to do anything for the Prambanan Temple area during the Prambanan Jazz Festival. This is because people already feel more like doing something for Prambanan Temple itself. After all, they feel Prambanan Temple is part of them, not because of PJF.

14) More Entertainment Opportunities

The community cannot make the PJF as a means of entertainment for them, and the community does not get a special ticket classification. This is because the ticket prices are too high for the economic conditions of the people around Prambanan Temple so that people cannot enjoy the PJF show directly in addition to the faint voices that can be heard by the residents with the closest home distance to Prambanan Temple.

15) Strengthening of Local Values and Traditions

Prambanan Jazz Festival does not preserve local culture and does not conflict with the local culture. This can happen because Prambanan Jazz Festival is a music festival with the Jazz genre that is known to Jazz music is a culture from outside Indonesia so that PJF displays outside music and not bring preservation of local culture. But the PJF does not conflict with local culture because Jazz is synonymous with calm and harmony so that these two things are still pleasing to the value of local culture.

16) Changes in Community Structure

Prambanan Jazz Festival does not make structural changes in society. This happened because the distance of their residence was not too close to the location of the Prambanan Temple area. So that the direct impact on society is less felt.
17) Commercialization of Activities which May be of A Personal or Private Nature This Prambanan Jazz Festival does not give a significant economic impact on the local community. Therefore the implementation of Prambanan Jazz Festival does not trigger the price changes that will be felt by the people around the Prambanan Temple area.

18) Culture Shock

Prambanan Jazz Festival did not cause a cultural shock to the people around the Prambanan Temple area. This is because the local community around the Prambanan temple area has become accustomed to meeting cultural differences that have been present since the Prambanan Temple became a tourist attraction, so this did not cause the community to be shocked because of the cultural differences that came from the implementation of the Prambanan Jazz Festival.

19) Dislocation of Local Residents

There is no area movement carried out by the community, and there is no area that cannot be entered by the local community due to the implementation of the Prambanan Jazz Festival. This means that the implementation of the Prambanan Jazz Festival does not disturb the surrounding community which must make them evacuate to other places because of this event

20) Heritage Destruction

Prambanan Jazz Festival does not cause potential or real damage to the cultural heritage around the Prambanan Temple area. This is because the implementation of Prambanan Jazz Festival is in zone 2 where the zone is a commercial zone where all the activities of the event are carried out and is not an area where the cultural heritage (Candi) is located. Then there is no potential or real damage to this cultural heritage.

21) Increased in Housing Rent

Prambanan Jazz Festival does not cause an increase in the price of renting houses around the Prambanan Temple area. This is 
because most of the Prambanan Jazz Festival event visitors are people with middle to upper economic groups, this can be seen from the festival ticket prices which are relatively quite expensive and can only be reached by people who are well-established or above average. This causes them to prefer to stay in hotels. Due to the low level of demand for visitors to the rental of guest houses/homestays around Prambanan temple, the price of rental homes also does not increase.

22) Increased Housing Prices

There was no increase in selling prices of houses around the Prambanan Temple area. This is because the implementation of Prambanan Jazz Festival did not have a significant impact on the local community which triggered them to increase the price of home sales in the area or even just triggered them to sell their homes because of the implementation of the Prambanan Jazz Festival. Also, the accommodation will be built to facilitate visitors, so that there is no offer to buy a house or land from the local community.

23) Increased Interethnic Tensions

Prambanan Jazz Festival does not cause ethnic tensions in the community around the Prambanan Temple area. This is because the local community around the Prambanan temple area has become accustomed to meeting ethnic differences that have been present since ancient times Prambanan Temple became a tourist attraction, so this did not cause tension in the community due to ethnic differences that came as a result of the Prambanan Jazz Festival.

24) Local Residents Avoid Places Frequent Visits by Visitor

There is no area in the Prambanan Temple area frequented by visitors which is avoided by the surrounding community due to the holding of the Prambanan Jazz Festival.

25) Prostitution Increase

Prambanan Jazz Festival does not trigger prostitution around the Prambanan Temple area. It was revealed by one of the speakers that prostitution had existed since before the Prambanan Jazz Festival was held, but there was no evidence of the increasing level of prostitution due to the implementation of the Prambanan Jazz Festival.

26) Poor Visitor Behaviour

There were no problems that occurred due to the behaviour of visitors to the holding of the Prambanan Jazz Festival. This is because the characters of the Prambanan Jazz Festival visitors themselves are partly from the upper-middle class who are educated and educated visitors who can maintain their manners in an environment, especially in the surrounding communities of Prambanan.

27) Road Closures

Crowd permits and road use permits have been carried out by the organizer. Besides, a road closure is not needed for the implementation of Prambanan Jazz Festival, meaning that this activity does not interfere with the activities of road users around the Prambanan Temple area.

28) Disruption of Daily Life

The community does not feel disturbed in their daily activities due to the holding of the Prambanan Jazz Festival. This is because the implementation of Prambanan Jazz Festival is not very direct in contact with the community either because of the distance between the venue and the village and the interaction between the implementation of Prambanan Jazz Festival and the local community which is considered minimal.

29) Interruption of Normal Business

The community does not feel disturbed by their business activities due to the implementation of Prambanan Jazz Festival. This is because the implementation of the Prambanan Jazz Festival is purely within the Prambanan temple area and does not come into direct contact with the community at all, so there is no economic impact that interferes with local community business activities. 
30) Resident Exodus

Prambanan Jazz Festival does not cause people to move to areas or temporarily evacuate to other places. This is because technically the implementation of Prambanan Jazz Festival does not use the area outside the Prambanan Temple area.

31) Disruption of Lifestyle

There is no change in people's lifestyles due to the implementation of the Prambanan Jazz Festival. This happens because the local community around Prambanan Temple itself is accustomed to the arrival of foreign cultures that enter their territory. After all, Prambanan Temple itself is a tourist attraction that has long been visited by domestic and foreign tourists who carry diverse cultures from their respective regions.

32) Media Impact

There was no increase in coverage by the media around Prambanan Temple after the holding of the Prambanan Jazz Festival.

33) Community Apathy and Antagonism

Some local people do not feel disturbed or object to the implementation of the Prambanan Jazz Festival.

34) Crime Rates Increase

There was no increase in crime around Prambanan due to the holding of the Prambanan Jazz Festival.

35) Destruction of Cultural Heritage

Prambanan Jazz Festival does not cause damage to cultural heritage around the Prambanan Temple area. This is a good thing for the organizers of the Prambanan Jazz Festival and the surrounding community.

36) Satisfied the Ambitions of the Political Elite

Prambanan Jazz Festival is not an event entrusted by politicians. This is because this event is purely a business activity carried out by the EO, namely PT Rajawali.

\section{b. Environmental Impact}

1) Raising Awareness of Environmental Issues
Prambanan Jazz Festival has less influence on environmental care branding. This is due to the residence of respondents who are still around the Prambanan Temple and Ratu Boko Temple, which are tourist areas. Therefore the community has become accustomed to maintaining the cleanliness of the environment to support the comfort of visitors who visit the Prambanan Temple and Ratu Boko Temple.

2) Development of Wasteland Based on data findings, all respondents stated that Prambanan Jazz Festival did not cause garbage problems.

3) Transport Improves

Community involvement in the provision and management of transportation is considered low. Only a few people from Taman Martani Village were involved as parking attendants during the event.

4) Increases Accommodation

Community involvement in providing accommodation is still low. In addition, the organizers did not invite the community to cooperate in providing accommodation.

5) Improves Traffic Conditions

Residents do not feel disturbed by the congestion caused by the holding of the Prambanan Jazz Festival. This is due to the limited use of venues in the temple park area and has a large parking area. The condition of the road, which is a crossprovincial road with a wide road width is also one factor that does not mean significant congestion.

6) Improves Site's Appearance

There is no increase in the beauty of the area around the temple associated with the organization. This is because of the PT. Prambanan Temple Tourism Park, Ratu Boko, and Borobudur have their standards for the beauty of the temple area.

7) Improves Roads

Prambanan Jazz Festival has less impact on improving accessibility in the surrounding area seen from the absence of road repairs.

8) Sanitation Improves 
The use of portable toilets is used as a solution by organizers to fulfil sanitation needs during the implementation.

9) Improves Traffic Signage

There is no permanent addition of road signs. Moreover, using non-permanent signage besides reducing the risk of damage to the environment can also make it easier for visitors to know the direction of certain areas during the implementation.

10) Long Term Conservation

Prambanan Jazz Festival activities do not have a special impact on the conservation of the environment around Prambanan Temple.

11) Site/Location Damage - Short - and Long Term

There was no damage to facilities belonging to the local community after the holding of the Prambanan Jazz Festival. This is because ticket prices are quite high and jazz fans are usually from the uppermiddle-class, so visitors already have the awareness to maintain facilities around the location.

12) Waste and Pollution

There is no pollution that disturbs the surrounding community. The garbage caused by Prambanan jazz festival activities has been managed by the temple tourism park.

13) Noise Pollution

People generally do not feel any noise pollution. The head of Pulirjo Hamlet who lives just $300 \mathrm{~m}$ from the location of the operation, also stated that he did not feel any noise pollution. This is because the location is very extensive so that the noise generated does not reach the homes of residents.

14) Traffic Disruption and Congestion There is no congestion which means that in the Prambanan temple area and the people are used to seeing the number of vehicles in the Prambanan Temple road area every weekend.

15) Air Pollution

In general, residents do not feel air pollution such as dust, smoke, and others during the implementation of the Prambanan Jazz Festival event.

16) Increase Energy Demands and Other Natural Resources

There was no electricity or water disturbance during the Prambanan Jazz Festival event because the organizer had used a personal generator set.

17) Destruction of Natural Environment

There was no damage to the environment around the location of the Prambanan Jazz Festival. The grass that was damaged at the location of the operation due to being trampled by visitors was immediately handled by the organizer to the PT. TWC.

\section{c. Economic Impact}

1) Direct/Indirect Expenditure

There are no direct and indirect economic impacts from the implementation of the Prambanan Jazz Festival. This is because the surrounding community is less involved in the event.

2) Increased Property Value Due to Regeneration

The community around the Prambanan Jazz Festival activities have not increased the value of selling goods or property around the activity area. This is because the community has not seen any opportunities that might be a benefit for the surrounding community of the presence of Prambanan Jazz Festival.

3) Additional Trade and Business Development

Based on the findings, it is known that no new business has developed due to the implementation of the Prambanan Jazz Festival. This is because the organizers have not involved the surrounding community in providing businesses that support the ongoing Prambanan Jazz Festival.

4) Induced Development and Construction Expenditure

The absence of induction of construction and construction from the implementation of the Prambanan Jazz Festival.

5) Increases Tourist 
Prambanan Jazz Festival increases the number of tourists who come to Prambanan Temple during the event or after. This is a major contribution from the organizers in achieving the goals that have been built when holding the Prambanan Jazz Festival event.

6) Improved Economic Conditions

The community had not felt a change in the economic situation when the Prambanan Jazz Festival took place.

7) Increased Employment

Only a part of the community feels that there are new jobs, namely becoming parking attendants when the event takes place.

8) Event Product Extensions

Prambanan Jazz Festival can not be used as a product extension program for the government. This is because this event has not yet given a significant economic impact on stakeholders, except government officials and venue providers.

9) Cost of Failure to the Local/National Economy

The community felt this event was quite successful for the Event Organizer. However, Prambanan Jazz Festival did not give an economic influence because the community was not involved in the event, only $20 \%$ of the community was involved because of the business location of the people who faced the Prambanan Temple area directly.

10) Inflated Price of Products, Services, and Amenities

Prambanan Jazz Festival does not cause inflation of rising prices for goods, services, and amenities. The price of goods, services, and amenities remain the same before and after implementation.

11) Increased Living Cost Prambanan Jazz Festival does not increase living costs in the area around Prambanan Temple.

12) Unequal Distribution of Wealth Only a small portion of the community feels the economic benefits of organizing the Prambanan Jazz Festival event. The community does not feel significant economic benefits, only small traders whose business locations face directly to Prambanan Temple and hotels that provide accommodation for viewers who feel the benefits.

13) Increased Price of Daily Products

The community did not feel an increase in prices/items of daily necessities during the holding of the Prambanan Jazz Festival event.

\section{CONCLUSION}

Based on data analysis on the social impacts of Prambanan Jazz Festival, it was concluded that Prambanan Jazz Festival had a little social impact on local communities. The Prambanan Jazz Festival does not provide significant environmental impact from some of the main aspects of this study. In addition, the implementation of the Prambanan Jazz Festival has not affected the economy around the event area due to the absence of programs made by the event organizers to support the economy of the surrounding community.

However, there are several recommendations such as establish good communication with the government and local communities, the organizers socialized to the community through local governments such as sub-districts and villages and were invited as well as invited to social events and programs related to community involvement in the event. In addition, it promotes that the public can attend the event at special prices so that it can be an entertainment choice for the community.

Provide special ticket prices for people whose names are registered as residents in their respective lurah offices. Criteria for special tickets are as follows: One special ticket is only valid for one person, One special ticket is only valid for one day, Special ticket data collection can be through the coordinator of each village, Special ticket prices can be afforded by the local community but do not harm the committee as well (IDR 50,000 IDR 150,000 or USD 3.57 - 10.71) 
In addition, organizers can display event reports that can be accessed by the public so that everyone can find out how this implementation can have an impact on the surrounding community and not only to the organizers.

While community involvement in Prambanan Jazz Festival activities such as allocation of $20 \%$ of the operational team during the implementation comes from the local community, the community selection process by informing the local sub-district to recommend people who are considered capable of carrying out operational activities, organizers conduct selection on the community that has been recommended by the interview process, and notification of who is involved is done a maximum of 1 month before the implementation so that briefings and training can be conducted for the introduction of technology or systems that will be used in the implementation.

In addition of local cultural content in event content: First, the organizer cooperates with the Management of Prambanan Temple who has a relationship with the Ramayana Ballet Artist in filling out a few of the Prambanan Jazz Festival event slots. This activity is one form of preservation of the country's cultural heritage and can also be further introduced to visitors from foreign and domestic. In addition, community support can also be obtained if Prambanan Jazz Festival incorporates local cultural heritage content, which is proud of by the community around Prambanan Temple. Second, the organizers worked together with the government and the community in filling out a few of the Prambanan Jazz Festival event slots. The government as an initiative to establish and train the community of Ramayana dancers. In the villages around Prambanan Temple, the community is still very strongly related to the local government such as the lurah. The local people are also mostly creative people, for example, the people of Kebon Dalem Kidul Village who handicraft some of their communities have been sold abroad.
All of that was initiated by the village head of the Kebon Dalem Kidul village. So that the EO can start by discussing with the relevant village head and discussing filling out the event slots at PJF by local community arts and as a reward for the community, the EO provides free tickets to participants outside of their art Show-Day. Viewed from the results of data analysis and conclusions that the research team got, the research team recommended that the organizers work together to create a Green Homestay program with surrounding communities such as empowering ten houses in each village so that the following year's Prambanan Jazz Festival event could have a positive impact towards the economy of the community also to the organizers to be able to see this as an achievement goal between the event organizer and host community.

With the Green Homestay, the organizers can see the new business that is felt by the community from the implementation of the Festival. Green homestay as an alternative accommodation for the Festival visitors, and in the future, the implementation of Prambanan Jazz Festival can influence the community. Previously there was a Homestay program created by Nusamba bank which was spread in several hamlets around Prambanan Temple. So the organizers should have coordination with village heads and Nusamba banks regarding the Homestay program.

The organizer organizes local market and bazaar in collaboration with VillageOwned Enterprises (BUMD) to be able to involve the community in the series of Prambanan Jazz Festival events. Here the community can sell the work and the business they have later can also be exhibited to visitors who come. This activity can open new employment opportunities for the community and provide an economic distribution that is evenly distributed to each village that is located around Prambanan Temple.

The organizer notified the local subdistrict head to invite the community to participate in the bazaar; from the total booths available, the organizers allocated $20 \%$ of the 
space for the local community; the organizer invites community cooperation to be able to sell their products during the implementation of the Prambanan Jazz Festival.

\section{REFERENCES}

Adongo, R., (Sam) Kim, S., \& Elliot, S. (2019). "Give and take": A social exchange perspective on festival stakeholder relations. Annals of Tourism Research, 75(July 2018), 42-57. https://doi.org/10.1016/j.annals.2018.12. 005

Alimi, S. (2017). International Music Festival Prambanan. Retrieved from https://prambananjazz.com/about

Creswell, J. (2014). Research Design. (V. Knight, Ed.), Journal of Visual Languages \& Computing (4th ed., Vol. 11). Los Angeles: SAGE. Retrieved from https://www.m-

culture.go.th/mculture_th/download/kin g9/Glossary_about_HM_King_Bhumib ol_Adulyadej's_Funeral.pdf

Dwyer, L., Forsyth, P., \& Spurr, R. (2015). Estimating the Impact of Special Events on an Economy. Journal of Travel Research, 43(4), 351-359. https://doi.org/10.1177/0047287505274 648

Getz, D., \& Page, S. J. (2014). Progress and prospects for event tourism research. Tourism Management, 52, 593-631. https://doi.org/10.1016/j.tourman.2015. 03.007

Gong, Q. (2012). The Positive and Negative Economic Contributions of Mega sporting Events to Local Communities. William F. Harrah College of Hotel Administration. Retrieved from https://digitalscholarship.unlv.edu/cgi/vi ewcontent .cgi $?$ article $=2363 \&$ context $=$ th esesdissertations

Liu, D. (2016). Social impact of major sports events perceived by the host community.
International Journal of Sports Marketing and Sponsorship, 17(1), 7891. https://doi.org/10.1108/IJSMS-022016-005

Osaka, S., \& Bellamy, R. (2020). Natural variability or climate change? Stakeholder and citizen perceptions of extreme event attribution. Global Environmental Change, 62(July 2019), 102070.

https://doi.org/10.1016/j.gloenvcha.202 0.102070

Parent, M. M. (2016). Stakeholder perceptions of the democratic governance of major sports events. Sport Management Review, 19(4), 402-416. https://doi.org/10.1016/j.smr.2015.11.00 3

Raj, R., \& Musgrave, J. (2009). Event Management and Sustainability. Oxfordshire: CABI.

Slabbert, E., Africa, S., \& Oberholzer, S. (2011). Residents' perceptions of the impacts of the FIFA 2010 world cup, 2008-2011.

Sugiyono. (2015). penelitian \& pengembangan (Research and Development/R\&D). Bandung: Alfabeta. Sugiyono. (2017). Metode Penelitian Bisnis: Pendekatan Kuantitatif, Kualitatif, Kombinasi, dan R\&D. Bandung: Alfabeta.

Todd, L., Leask, A., \& Ensor, J. (2017). Understanding primary stakeholders' multiple roles in hallmark event tourism management. Tourism Management, 59, 494-509.

https://doi.org/10.1016/j.tourman.2016. 09.010

Wilson, J., Arshed, N., Shaw, E., \& Pret, T. (2017). Expanding the Domain of Festival Research: A Review and Research Agenda. International Journal of Management Reviews, 19(2), 195213. https://doi.org/10.1111/ijmr.12093 